\title{
Interdependence of oestrogen and insulin-like growth factor-I in the brain: potential for analysing neuroprotective mechanisms
}

\author{
Pablo Mendez, Iñigo Azcoitia ${ }^{\mathbf{1}}$ and Luis Miguel Garcia-Segura \\ Instituto Cajal, CSIC, E-28002 Madrid, Spain \\ ${ }^{1}$ Departamento de Biología Celular, Facultad de Biología, Universidad Complutense, E-28040 Madrid, Spain \\ (Requests for offprints should be addressed to L M Garcia-Segura, Instituto Cajal, CSIC, Avenida Doctor Arce 37, E-28002 Madrid, Spain; \\ Email:Imgs@cajal.csic.es)
}

\begin{abstract}
The actions of oestradiol in the brain involve interaction with growth factors, such as insulin-like growth factor-I (IGF-I). Many cells in the brain co-express receptors for oestradiol and IGF-I and both factors interact to regulate neural function. The relationship of oestrogen receptor $\alpha$ with IGF-I receptor through the mitogen-activated protein kinase and the phosphoinositide 3-kinase signalling pathways may represent the point of convergence used by
\end{abstract}

these two factors to cooperatively modulate neuritic growth, synaptic plasticity, neuroendocrine events, reproductive behaviour and neuronal survival. In addition, Akt and glycogen synthase kinase $3 \beta$ are key molecular targets to explain the interaction of oestrogen and IGF-I receptor signalling in the promotion of neuroprotection.

Journal of Endocrinology (2005) 185, 11-17

\section{Introduction}

The nervous system is a target for the ovarian hormone oestradiol. This hormone regulates brain development and function, acting on neurons, synapses and glial cells (Chowen et al. 2000, McEwen 2002). For many years it was considered that the actions of oestradiol in the brain were restricted to areas involved in neuroendocrine regulation and the control of sex behaviour. Today it has become evident that oestradiol exerts a broad spectrum of actions, including neuroprotective effects, in many brain areas that are not directly related to reproduction (Chowen et al. 2000, Garcia-Segura et al. 2001, Stein 2001, Wise et al. 2001, McEwen 2002). One of the main mechanisms of action of oestradiol in the brain, as in other organs, is the activation of nuclear oestrogen receptors. These receptors belong to the steroid/thyroid nuclear receptor superfamily, and once activated homo- or heterodimerize, interact with DNA and recruit a cohort of transcriptional cofactors to the regulatory regions of target genes. The two mammalian oestrogen receptors cloned to date, $\alpha$ and $\beta$, are widely distributed through the central nervous system. In addition oestradiol exerts rapid membrane effects on neural cells, modulating ion channels, neurotransmitter transporters, levels of intracellular calcium and other second messengers and phosphorylation of different kinases (Chowen et al. 2000, Cardona-Gomez et al. 2001, Stein 2001, Wise et al. 2001, McEwen 2002).

In this review we focus on one of the mechanisms of action of oestradiol in the brain: the interaction with the signalling of insulin-like growth factor-I (IGF-I). First, we present several lines of evidence of crosstalk between oestradiol and IGF-I in the brain. Then we analyse the implications of this crosstalk for neuroprotection. Finally we discuss the molecular mechanisms involved in the interaction of oestrogen receptors and IGF-I receptors in the brain and their potential implications for neuroprotection.

\section{Crosstalk between oestradiol and IGF-I in the brain}

In several cellular systems there is a crosstalk between the signalling of oestradiol and IGF-I (Ghahary et al. 1990, Klotz et al. 2002, Sato et al. 2002). Among the most studied examples are breast cancer cells: both factors play a role in the development and proliferation of breast cancer cells and show synergistic interactions in the activation of cell-cycle components, resulting in increased proliferation rates (Dupont \& Le Roith 2001, Hamelers et al. 2002, Martin \& Stoica 2002, Hamelers \& Steenbergh 2003, Song et al. 2004, Thordarson et al. 2004). Interactions 


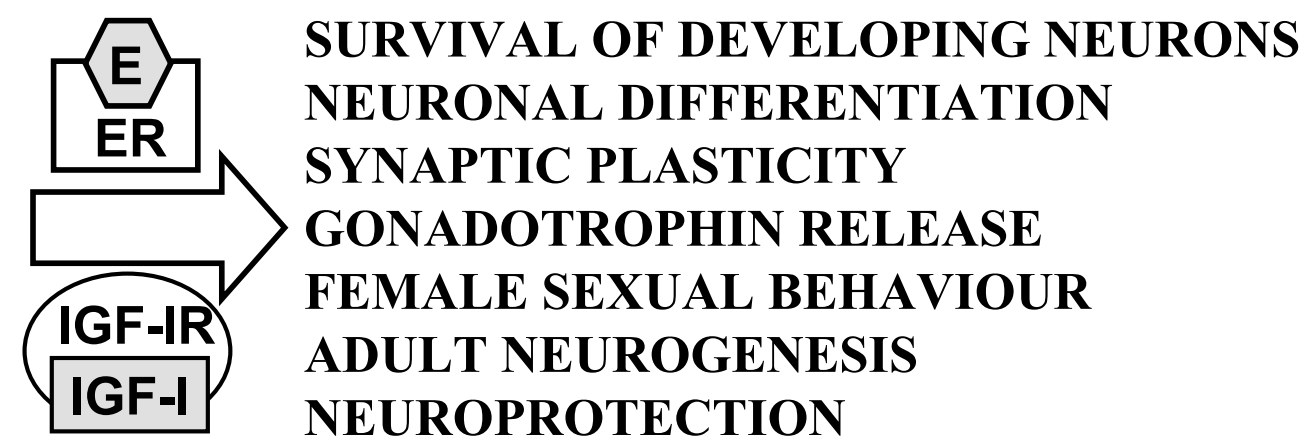

Figure 1 Neural events where interactions between oestradiol (E) and IGF-I, or between oestrogen receptors (ER) and IGF-I receptors (IGF-IR), have been documented.

between IGF-I and oestradiol have been detected in the nervous system as well. As an endocrine signal, IGF-I represents a link between the growth and reproductive axes and the interaction between IGF-I and oestradiol in the brain may be of particular physiological relevance for the regulation of growth, sexual maturation and adult neuroendocrine function.

Analysis of the distribution of IGF-I receptor and of the two known forms of oestrogen receptors $(\alpha$ and $\beta)$ in the rat brain reveals that many brain cells express both types of receptor and that most neural cells expressing IGF-I receptor also express oestrogen receptors (Cardona-Gomez et al. 2000a, Garcia-Segura et al. 2000). This suggests that oestrogen and IGF-I may interact in different brain regions to regulate neural function. Such interactions have been reported in brain areas involved in neuroendocrine control (Fig. 1). For instance, there is an interdependence of oestrogen receptors and IGF-I receptor in the promotion of the survival and differentiation of developing hypothalamic neurons (Toran-Allerand et al. 1988, Dueñas et al. 1996, Cambiasso et al. 2000, Carrer \& Cambiasso 2002). Both factors interact as well in the control of synaptic plasticity in the arcuate nucleus, a key centre for neuroendocrine regulation of the growth and reproductive axes. Oestradiol increases IGF-I accumulation in the arcuate nucleus during the oestrous cycle (Garcia-Segura et al. 1994) and both oestrogen receptors and IGF-I receptor are involved in the induction of synaptic and glial plastic modifications in this brain area (Fernandez-Galaz et al. 1997, 1999, Cardona-Gomez et al. 2000b). Furthermore, oestradiol and IGF-I interact in the control of luteinizing hormone secretion at the hypothalamic level (Hiney et al. 2004), and blockade of IGF-I receptor during oestrogen priming blocks oestrogen-induced luteinizing hormone release and partially inhibits hormone-dependent reproductive behaviour (Quesada \& Etgen 2002, Etgen 2003, Etgen \& Acosta-Martinez 2003).

Another functional outcome of the interaction of IGF-I with oestrogen in the brain is the regulation of adult neurogenesis. Neural precursors located in the subgranular zone of the dentate gyrus of the hippocampus proliferate in adult rodents. The newly generated neurons are functional, integrate in hippocampal circuits and may be involved in certain forms of hippocampal-dependent learning. IGF-I and oestradiol are among the molecules that have been identified as modulators of adult neurogenesis (Tanapat et al. 1999, Trejo et al. 2001). The intracerebroventricular administration of the oestrogen receptor antagonist ICI 182780 blocks IGF-I-induced neurogenesis in adult ovariectomized rats (Perez-Martin et al. 2003), suggesting that oestrogen receptors are involved in the action of IGF-I on adult hippocampal neurogenesis. This interaction of IGF-I with oestrogen receptors may directly occur in the proliferating cells, since they express receptors for both IGF-I and oestrogen (Perez-Martin et al. 2003).

\section{Interaction of oestradiol and IGF-I on neuroprotection}

IGF-I and oestradiol have neuroprotective properties and prevent neuronal cell death in different experimental models of neurodegenerative diseases (Garcia-Segura et al. 2001, Carro et al. 2003). The interaction of IGF-I and oestradiol in neuroprotection has been assessed in ovariectomized rats, using systemic administration of kainic acid to induce degeneration of hippocampal hilar neurons (Azcoitia et al. 1999), an experimental model of excitotoxic cell death. Both the systemic administration of oestradiol and the intracerebroventricular infusion of IGF-I prevent hilar neuronal loss induced by kainic acid. The neuroprotective effect of oestradiol is blocked by the intracerebroventricular infusion of the IGF-I receptor antagonist JB-1, while the neuroprotective effect of IGF-I is blocked by the intracerebroventricular infusion of the oestrogen receptor antagonist ICI 182780 (Azcoitia et al. 1999). Similar results have been obtained after the unilateral infusion of 6-hydroxydopamine into the medial forebrain bundle to lesion the nigrostriatal dopaminergic pathway, a model of Parkinson's disease. Pretreatment with oestrogen or IGF-I significantly prevents the loss of 
substantia nigra compacta neurons and the related motor disturbances. Blockage of IGF-I receptors by intracerebroventricular JB-1 attenuates the neuroprotective effects of both oestrogen and IGF-I (Quesada \& Micevych 2004). These findings suggest that the neuroprotective actions of oestradiol and IGF-I after brain injury depend on the coactivation of both oestrogen receptors and IGF-I receptor.

It should be noted that the studies which up to now have assessed the interactions of oestrogen receptors and IGF-I receptors in the brain in vivo have been conducted on ovariectomized females. We may assume that similar interactions will occur in the brains of intact females and in the brains of males. However, the outcome of these interactions may be different in males than in females. Although it is known that oestrogen and IGF-I may exert neuroprotective actions in male rodents (Carro et al. 2003, Garcia-Segura et al. 2001, 2003), there are several reports of sex differences in the response to brain injury and in the neuroprotective actions of oestradiol (Roof \& Hall 2000, Garcia-Segura et al. 2001, Galanopoulou et al. 2003, Hilton et al. 2003). Furthermore, the potential effects of androgens on the interaction of oestrogen receptors and IGF-I receptors in the brain have not been explored.

\section{Mechanisms of crosstalk between oestradiol and IGF-I in the brain}

The abundant coexpression of oestrogen receptors with IGF-I receptor in neurons and glia in the brain (CardonaGomez et al. 2000a, Garcia-Segura et al. 2000) indicates that interactions of the intracellular signalling pathways of IGF-I receptor and oestrogen receptors are possible in many brain cells. In different cell lines, including neuroblastoma cells (Ma et al. 1994), IGF-I may activate oestrogen receptors in the absence of oestradiol. Whether or not this is also valid for the brain in vivo is unknown. However, both in vitro and in vivo studies have shown that oestradiol regulates the expression of IGF-I receptors in neural tissue (Cardona-Gomez et al. 2001, El-Bakri et al. 2004) and activates the two main signal transduction cascades coupled to the IGF-I receptor: the mitogen-activated protein kinase (MAPK) and the phosphoinositide 3-kinase (PI3K) signalling pathways.

Estradiol induces a rapid activation of extracellularsignal-regulated kinase (ERK) in primary cultures of astroglia (Ivanova et al. 2001) and in explants of cerebral cortex (Toran-Allerand et al. 1999, Singh et al. 2000, Setalo et al. 2002). In addition, the oestradiol-induced activation of ERK may be detected in vivo after systemic administration of the hormone (Cardona-Gomez et al. 2003). ERK activation may be involved in the induction of neurite arborization of cholinergic neurons by oestradiol (Dominguez et al. 2004) and in the neuroprotective effects of the hormone (Singer et al. 1999, Garcia-Segura et al.
2000, Kuroki et al. 2001). Oestradiol also induces the phosphorylation of protein kinase $\mathrm{B}$, also known as the kinase Akt, in primary neuronal cultures, in cerebral cortical explants and in the adult rat brain in vivo (Singh 2001, Cardona-Gomez et al. 2002, Ivanova et al. 2002, Wilson et al. 2002, Znamensky et al. 2003). Furthermore, IGF-I and estradiol act synergistically to increase Akt activity, but not ERK, in the rat brain (Cardona-Gomez et al. 2002). Activation of Akt may regulate oestradiolinduced synaptic plasticity (Znamensky et al. 2003) and may also be involved in the neuroprotective effects of oestradiol (Garcia-Segura et al. 2000, Honda et al. 2000, Zhang et al. 2001, Yu et al. 2004).

Glycogen synthase kinase $3 \beta$ (GSK3 3 ), downstream of Akt, may also be a point of interaction of oestrogen and IGF-I signalling. Physiological phosphorylation of microtubule-associated proteins by GSK3 $\beta$ may be involved in the regulation of microtubule dynamics, neuritic growth, synaptogenesis and synaptic plasticity (Hall et al. 2000). However, under pathological conditions, GSK3 $\beta$ may be responsible for the hyperphosphorylation of Tau in Alzheimer's disease (Lovestone et al. 1994) and its inhibition is associated with the activation of survival pathways in neurons (Cross et al. 1995). Interestingly, oestradiol regulates the activity of GSK3 $\beta$ and decreases the phosphorylation of $\mathrm{Tau}$ in the rat hippocampus in vivo (Cardona-Gomez et al. 2004). Furthermore, oestradiol increases the association of Tau with phosphorylated GSK $3 \beta$, with the p85 subunit of the PI3K and with $\beta$-catenin, another substrate of GSK3 $\beta$ (Cardona-Gomez et al. 2004). These observations are coherent with results showing that systemic administration of oestradiol to adult ovariectomized rats results in a transient increase in tyrosine phosphorylation of the IGF-I receptor, in a transient interaction of the IGF-I receptor with the oestrogen receptor $\alpha$, but not $\beta$, and in an enhanced interaction of oestrogen receptor $\alpha$ with the p85 subunit of the PI3K in the brain (Mendez et al. 2003). All these findings suggest that oestrogen receptor $\alpha$ may affect IGF-I actions in the brain by an interaction with some of the components of IGF-I signalling, such as the IGF-I receptor, PI3K and GSK3 $\beta$. A hypothetical model for these interactions is presented in Figure 2.

The interaction of oestrogen receptor $\alpha$ with the signalling pathways of IGF-I receptor in the brain may explain the interdependence of oestradiol and IGF-I in the regulation of different neural events. ERK and Akt may be involved in the interaction of IGF-I and oestradiol in the regulation of neuronal differentiation, synaptic function, synaptic remodelling, neuroprotection and sexual behaviour. The synergistic interaction of IGF-I and oestradiol in the phosphorylation of Akt may be critical for neuroprotective actions. Akt regulates several transcription factors that may be involved in the control of neuronal survival, such as cAMP-response-element-binding protein (CREB; Pugazhenthi et al. 2000), nuclear factor $\kappa$ 


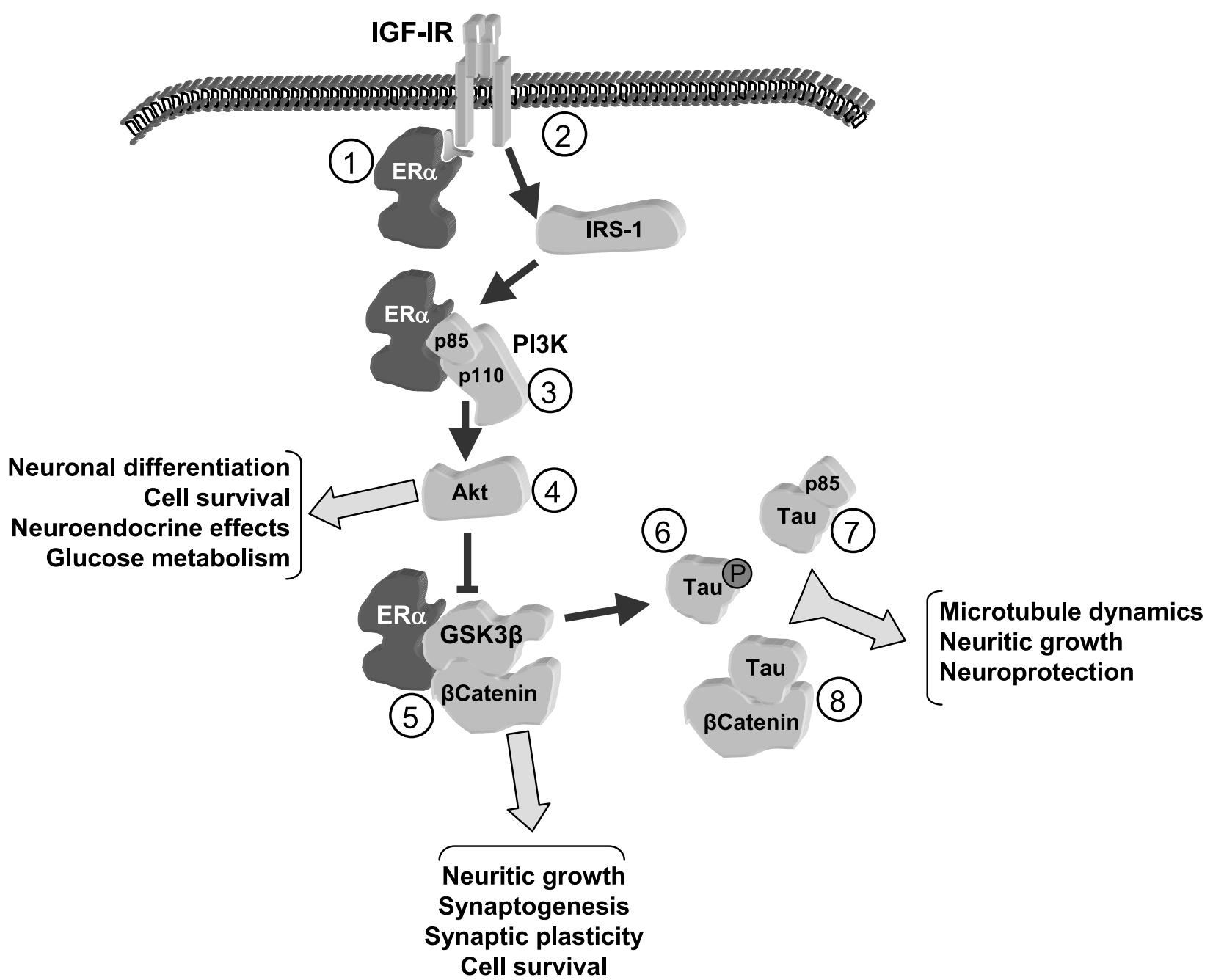

Figure 2 Proposed model for the interaction of oestradiol and IGF-I in the brain. Oestradiol interacts with IGF-I at different levels, regulating the activity and association of different proteins involved in the cellular response to IGF-I. (1) Oestradiol induces the association of oestrogen receptor $\alpha$ (ER $\alpha$ ) with IGF-I receptor (IGF-IR), probably through an adapter protein. (2) Oestradiol increases IGF-I receptor phosphorylation.(3) Oestradiol treatment modulates the interaction between oestrogen receptor $\alpha$ and p85. (4) Oestradiol regulates the activity of protein kinases, increasing Akt phosphorylation. (5) Oestrogen receptor $\alpha$ interacts with GSK3 $\beta$ and $\beta$-catenin, and oestradiol decreases GSK3 $\beta$ activity, which in turn (6) decreases Tau phosphorylation. $(7,8)$ The associations of p85 and $\beta$-catenin with Tau are also increased upon oestradiol treatment in the brain. Some potential functional outcomes of these interactions are indicated in the figure. IRS-1: insulin receptor substrate-1.

(NF-kB; Kane et al. 1999) and several members of the Forkhead family (Brunet et al. 1999, Kops et al. 1999, Tang et al. 1999). In addition, activation of Akt results in the phosphorylation of the Bcl-2 family member Bad and this may suppress Bad-induced cell death (Datta et al. 1997, del Peso et al. 1997). Furthermore, Akt activation enhances Bcl-2 promoter activity (Pugazhenthi et al. 2000) and both IGF-I and oestrogen induce Bcl-2 expression in neurons. Interestingly, IGF-I receptor activation is necessary for the induction of $\mathrm{Bcl}-2$ by estradiol in the adult brain (Cardona-Gomez et al. 2003). Also downstream of Akt, IGF-I and oestradiol may interact on the regulation of microtubule dynamics, neuritic growth, synaptogenesis, synaptic plasticity and neuronal survival, acting on GSK3 $\beta$ and on its substrates, $\beta$-catenin and Tau (Cardona-Gomez et al. 2004).

\section{Conclusions}

The studies reviewed in this paper indicate that the mechanisms of intracellular signalling of IGF-I and oestradiol are intimately associated in the nervous system. Oestrogen receptor $\alpha$ appears to be part of the signalling 
mechanism of IGF-I in the brain. In turn, oestradiol activates IGF-I receptor signalling in neurons and glia. This interaction between IGF-I and oestradiol appears to be relevant for the neuroprotective effects of both factors.

\section{Acknowledgements}

We acknowledge financial support from Ministerio de Ciencia y Tecnología, Spain (SAF 2002-00652), Comunidad de Madrid (08.5/0002.2/2003) and the Commission of the European Communities, specific RTD programme 'Quality of Life and Management of Living Resources' (QLK6-CT-2000-00179). The authors declare that there is no conlict of interest that would prejudice the impartiality of this scientific work.

\section{References}

Azcoitia I, Sierra A \& Garcia-Segura LM 1999 Neuroprotective effects of estradiol in the adult rat hippocampus: interaction with insulin-like growth factor-I signalling. Journal of Neuroscience Research 58 815-822.

Brunet A, Bonni A, Zigmond MJ, Lin MZ, Juo P, Hu LS, Anderson MJ, Arden KC, Blenis J \& Greenberg ME 1999 Akt promotes cell survival by phosphorylating and inhibiting a Forkhead transcription factor. Cell 96 857-868.

Cambiasso MJ, Colombo JA \& Carrer HF 2000 Differential effect of oestradiol and astroglia-conditioned media on the growth of hypothalamic neurons from male and female rat brains. European Journal of Neuroscience 12 2291-2298.

Cardona-Gomez GP, DonCarlos L \& Garcia-Segura LM 2000a Insulin-like growth factor I receptors and estrogen receptors colocalize in female rat brain. Neuroscience $\mathbf{9 9} 751-760$.

Cardona-Gomez GP, Trejo JL, Fernandez AM \& Garcia-Segura LM $2000 b$ Estrogen receptors and insulin-like growth factor-I receptors mediate estrogen-dependent synaptic plasticity. NeuroReport 11 $1735-1738$

Cardona-Gomez GP, Mendez P, DonCarlos LL, Azcoitia I \& Garcia-Segura LM 2001 Interactions of estrogens and insulin-like growth factor-I in the brain: implications for neuroprotection. Brain Research Reviews 37 320-334.

Cardona-Gomez GP, Mendez P \& Garcia-Segura LM 2002 Synergistic interaction of estradiol and insulin-like growth factor-I in the activation of PI3K/Akt signaling in the adult rat hypothalamus. Molecular Brain Research 107 80-88.

Cardona-Gomez GP, Mendez P, DonCarlos LL, Azcoitia I \& Garcia-Segura LM 2003 Interactions of estrogen and insulin-like growth factor-I in the brain: molecular mechanisms and functional implications. Journal of Steroid Biochemistry and Molecular Biology $\mathbf{8 3}$ 211-217.

Cardona-Gomez P, Perez M, Avila J, Garcia-Segura LM \& Wandosell F 2004 Estradiol inhibits GSK3 and regulates interaction of estrogen receptors, GSK3 and beta-catenin, in the hippocampus. Molecular and Cellular Neuroscience 25 363-373.

Carrer HF \& Cambiasso MJ 2002 Sexual differentiation of the brain: genes, estrogen, and neurotrophic factors. Cellular and Molecular Neurobiology 22 479-500.

Carro E, Trejo JL, Nunez A \& Torres-Aleman I 2003 Brain repair and neuroprotection by serum insulin-like growth factor I. Molecular Neurobiology 27 153-162.

Chowen JA, Azcoitia I, Cardona-Gomez GP \& Garcia-Segura LM 2000 Sex steroids and the brain: lessons from animal studies. Journal of Pediatric Endocrinology and Metabolism 13 1045-1066.
Cross DA, Alessi DR, Cohen P, Andjelkovich M \&, Hemmings BA 1995 Inhibition of glycogen synthase kinase-3 by insulin mediated by protein kinase B. Nature 378 785-789.

Datta SR, Dudek H, Tao X, Masters S, Fu H, Gotoh Y \& Greenberg ME 1997 Akt phosphorylation of BAD couples survival signals to cell-intrinsic machinery. Cell 91 231-241.

del Peso L, Gonzalez-Garcia M, Page C, Herrera R \& Nunez G 1997 Interleukin-3-induced phosphorylation of BAD through the protein kinase Akt. Science 278 687-689.

Dominguez R, Jalali C \& de Lacalle S 2004 Morphological effects of estrogen on cholinergic neurons in vitro involves activation of extracellular signal-regulated kinases. Journal of Neuroscience $\mathbf{2 4}$ 982-990.

Dueñas M, Torres-Aleman I, Naftolin F \& Garcia-Segura LM 1996 Interaction of insulin-like growth factor-1 and estradiol signaling pathways on hypothalamic neuronal differentiation. Neuroscience $\mathbf{7 4}$ 531-539.

Dupont J \& Le Roith D 2001 Insulin-like growth factor 1 and oestradiol promote cell proliferation of MCF-7 breast cancer cells: new insights into their synergistic effects. Molecular Pathology $\mathbf{5 4}$ 149-154.

El-Bakri NK, Islam A, Suliman I, Lindgren U, Winblad B \& Adem A 2004 Ovariectomy and gonadal hormone treatment: effects on insulin-like growth factor-1 receptors in the rat brain. Growth Hormone and IGF Research 14 388-393.

Etgen AM 2003 Ovarian steroid and growth factor regulation of female reproductive function involves modification of hypothalamic alpha 1-adrenoceptor signaling. Annals of the New York Academy of Sciences 1007 153-161.

Etgen AM \& Acosta-Martinez M 2003 Participation of growth factor signal transduction pathways in estradiol facilitation of female reproductive behavior. Endocrinology 144 3828-3835.

Fernandez-Galaz MC, Morschl E, Chowen JA, Torres-Aleman I, Naftolin F \& Garcia-Segura LM 1997 Role of astroglia and insulin-like growth factor-I in gonadal hormone-dependent synaptic plasticity. Brain Research Bulletin 44 525-531.

Fernandez-Galaz MC, Naftolin F \& Garcia-Segura LM 1999 Phasic synaptic remodelling of the arcuate nucelus during the estrous cycle depends on insulin-like growth factor-I receptor activation. Journal of Neuroscience Research 55 286-292.

Galanopoulou AS, Alm EM \& Veliskova J 2003 Estradiol reduces seizure-induced hippocampal injury in ovariectomized female but not in male rats. Neuroscience Letters 342 201-205.

Garcia-Segura LM, Chowen JA, Parducz A \& Naftolin F 1994 Gonadal hormones as promoters of structural synaptic plasticity: cellular mechanisms. Progress in Neurobiology 44 279-307.

Garcia-Segura LM, Cardona-Gomez GP, Chowen JA \& Azcoitia I 2000 Insulin-like growth factor-I receptors and estrogen receptors interact in the promotion of neuronal survival and neuroprotection. Journal of Neurocytology 29 425-437.

Garcia-Segura LM, Azcoitia I \& DonCarlos LL 2001 Neuroprotection by estradiol. Progress in Neurobiology 63 29-60.

Garcia-Segura LM, Veiga S, Sierra A, Melcangi RC \& Azcoitia I 2003 Aromatase: a neuroprotective enzyme. Progess in Neurobiology 71 31-41.

Ghahary A, Chakrabarti S \& Murphy LJ 1990 Localization of the sites of synthesis and action of insulin-like growth factor-I in the rat uterus. Molecular Endocrinology 4 191-195.

Hall AC, Lucas FR \& Salinas PC 2000 Axonal remodeling and synaptic differentiation in the cerebellum is regulated by WNT-7a signaling. Cell 100 525-535.

Hamelers IH \& Steenbergh PH 2003 Interactions between estrogen and insulin-like growth factor signaling pathways in human breast tumor cells. Endocrine-related Cancer 10 331-345.

Hamelers IH, van Schaik RF, van Teeffelen HA, Sussenbach JS \& Steenbergh PH 2002 Synergistic proliferative action of insulin-like 
growth factor I and 17 beta-estradiol in MCF-7S breast tumor cells. Experimental Cell Research 273 107-117.

Hilton GD, Nunez JL \& McCarthy MM 2003 Sex differences in response to kainic acid and estradiol in the hippocampus of newborn rats. Neuroscience 116 383-391.

Hiney JK, Srivastava V, Dearth RK \& Dees WL 2004 Influence of estradiol on insulin-like growth factor-1-induced luteinizing hormone secretion. Brain Research 1013 91-97.

Honda K, Sawada H, Kihara T, Urushitani M, Nakamizo T, Akaike A \& Shimohama S 2000 Phosphatidylinositol 3-kinase mediates neuroprotection by estrogen in cultured cortical neurons. Journal of Neuroscience Research 60 321-327.

Ivanova T, Karolczak M \& Beyer C 2001 Estrogen stimulates the mitogen-activated protein kinase pathway in midbrain astroglia. Brain Research 889 264-269.

Ivanova T, Mendez P, Garcia-Segura LM \& Beyer C 2002 Rapid stimulation of the PI3-kinase/Akt signalling pathway in developing midbrain neurones by oestrogen. Journal of Neuroendocrinology 14 73-79.

Kane LP, Shapiro VS, Stokoe D \& Weiss A 1999 Induction of NF-kappaB by the Akt/PKB kinase. Current Biology 9 601-604.

Klotz DM, Hewitt SC, Ciana P, Raviscioni M, Lindzey JK, Foley J, Maggi A, DiAugustine RP \& Korach KS 2002 Requirement of estrogen receptor-alpha in insulin-like growth factor-1 (IGF-1)-induced uterine responses and in vivo evidence for IGF-1/estrogen receptor cross-talk. Journal of Biological Chemistry 277 8531-8537.

Kops GJ, de Ruiter ND, De Vries-Smits AM, Powell DR, Bos JL \& Burgering BM 1999 Direct control of the Forkhead transcription factor AFX by protein kinase B. Nature 398 630-634

Kuroki Y, Fukushima K, Kanda Y, Mizuno K \& Watanabe Y 2001 Neuroprotection by estrogen via extracellular signal-regulated kinase against quinolinic acid-induced cell death in the rat hippocampus. European Journal of Neuroscience 13 472-476.

Lovestone S, Reynolds CH, Latimer D, Davis DR, Anderton BH, Gallo JM, Hanger D, Mulot S, Marquardt B, Stabel S et al. 1994 Alzheimer's disease-like phosphorylation of the microtubule-associated protein tau by glycogen synthase kinase-3 in transfected mammalian cells. Current Biology 4 1077-1086.

Ma ZQ, Santagati S, Patrone C, Pollio G, Vegeto E \& Maggi A 1994 Insulin-like growth factors activate estrogen receptor to control the growth and differentiation of the human neuroblastoma cell line SK-ER3. Molecular Endocrinology 8 910-918.

Martin MB \& Stoica A 2002 Insulin-like growth factor-I and estrogen interactions in breast cancer. Journal of Nutrition 132 3799S-3801S.

McEwen B 2002 Estrogen actions throughout the brain. Recent Progress in Hormone Research 57 357-384.

Mendez P, Azcoitia I \& Garcia-Segura LM 2003 Estrogen receptor alpha forms estrogen-dependent multimolecular complexes with insulin-like growth factor receptor and phosphatidylinositol 3-kinase in the adult rat brain. Molecular Brain Research 112 170-176.

Perez-Martin M, Azcoitia I, Trejo JL, Sierra A \& Garcia-Segura LM 2003 An antagonist of estrogen receptors blocks the induction of adult neurogenesis by insulin-like growth factor-I in the dentate gyrus of adult female rat. European Journal of Neuroscience $\mathbf{1 8}$ 923-930.

Pugazhenthi S, Nesterova A, Sable C, Heidenreich KA, Boxer LM, Heasley LE \& Reusch JE 2000 Akt/protein kinase B up-regulates Bcl-2 expression through cAMP-response element-binding protein. Journal of Biological Chemistry 275, 10761-10766.

Quesada A \& Etgen AM 2002 Functional interactions between estrogen and insulin-like growth factor-I in the regulation of alpha $1 \mathrm{~B}$-adrenoceptors and female reproductive function. Journal of Neuroscience 22 2401-2048.
Quesada A \& Micevych PE 2004 Estrogen interacts with the IGF-1 system to protect nigrostriatal dopamine and maintain motoric behavior after 6-hydroxdopamine lesions. Journal of Neuroscience Research 75 107-116.

Roof RL \& Hall ED 2000 Estrogen-related gender difference in survival rate and cortical blood flow after impact-acceleration head injury in rats. Journal of Neurotrauma 17 1155-1169.

Sato T, Wang G, Hardy MP, Kurita T, Cunha GR \& Cooke PS 2002 Role of systemic and local IGF-I in the effects of estrogen on growth and epithelial proliferation of mouse uterus. Endocrinology $1432673-2679$.

Setalo G, Singh M, Guan X \& Toran-Allerand CD 2002 Estradiol-induced phosphorylation of ERK1/2 in explants of the mouse cerebral cortex: the roles of heat shock protein 90 (Hsp90) and MEK2. Journal of Neurobiology 50 1-12.

Singer CA, Figueroa-Masot XA, Batchelor RH \& Dorsa DM 1999 The mitogen-activated protein kinase pathway mediates estrogen neuroprotection after glutamate toxicity in primary cortical neurons. Journal of Neuroscience 19 2455-2463.

Singh M 2001 Ovarian hormones elicit phosphorylation of Akt and extracellular-signal regulated kinase in explants of the cerebral cortex. Endocrine 14 407-415.

Singh M, Setalo G, Guan X, Frail DE \& Toran-Allerand CD 2000 Estrogen-induced activation of the mitogen-activated protein kinase cascade in the cerebral cortex of estrogen receptor-alpha knock-out mice. Journal of Neuroscience 20 1694-1700.

Song RX, Barnes CJ, Zhang Z, Bao Y, Kumar R \& Santen RJ 2004 The role of Shc and insulin-like growth factor 1 receptor in mediating the translocation of estrogen receptor alpha to the plasma membrane. PNAS 101 2076-2081.

Stein DG 2001 Brain damage, sex hormones and recovery: a new role for progesterone and estrogen? Trends in Neuroscience 24 386-391.

Tanapat P, Hastings NB, Reeves AJ \& Gould E 1999 Estrogen stimulates a transient increase in the number of new neurons in the dentate gyrus of the adult female rat. Journal of Neuroscience 19 $5792-5801$

Tang ED, Nunez G, Barr FG \& Guan KL 1999 Negative regulation of the forkhead transcription factor FKHR by Akt. Journal of Biological Chemistry 274 16741-16746.

Thordarson G, Slusher N, Leong H, Ochoa D, Rajkumar L, Guzman R, Nandi S \& Talamantes F 2004 Insulin-like growth factor (IGF)-I obliterates the pregnancy-associated protection against mammary carcinogenesis in rats: evidence that IGF-I enhances cancer progression through estrogen receptor-alpha activation via the mitogen-activated protein kinase pathway. Breast Cancer Research 6 R423-R436.

Toran-Allerand CD, Ellis L \& Pfenninger KH 1988 Estrogen and insulin synergism in neurite growth enhancement in vitro: mediation of steroid effects by interactions with growth factors? Brain Research $46987-100$.

Toran-Allerand CD, Singh M \& Sétáló G 1999 Novel mechanisms of estrogen action in the brain: new players in an old story. Frontiers in Neuroendocrinology 20 97-121.

Trejo JL, Carro E \& Torres-Aleman I 2001 Circulating insulin-like growth factor I mediates exercise-induced increases in the number of new neurons in the adult hippocampus. Journal of Neuroscience 21 $1628-1634$

Wilson ME, Liu Y \& Wise PM 2002 Estradiol enhances Akt activation in cortical explant cultures following neuronal injury. Molecular Brain Research 102 48-54.

Wise PM, Dubal DB, Wilson ME, Rau SW, Bottner M \& Rosewell KL 2001 Estradiol is a protective factor in the adult and aging brain: understanding of mechanisms derived from in vivo and in vitro studies. Brain Research Reviews 37 313-319.

Yu X, Rajala RV, McGinnis JF, Li F, Anderson RE, Yan X, Li S, Elias RV, Knapp RR, Zhou X \& Cao W 2004 Involvement of 
insulin/phosphoinositide 3-kinase/Akt signal pathway in 17 beta-estradiol-mediated neuroprotection. Journal of Biological Chemistry 279 13086-13094.

Zhang L, Rubinow DR, Xaing G, Li BS, Chang YH, Maric D, Barker JL \& Ma W 2001 Estrogen protects against beta-amyloid-induced neurotoxicity in rat hippocampal neurons by activation of Akt. NeuroReport 12 1919-1923.

Znamensky V, Akama KT, McEwen BS \& Milner TA 2003 Estrogen levels regulate the subcellular distribution of phosphorylated
Akt in hippocampal CA1 dendrites. Journal of Neuroscience $\mathbf{2 3}$ 2340-2347.

Received 2 November 2004

Accepted 6 January 2005

Made available online as an

Accepted Preprint 10 January 2005 